\title{
MORPHOLOGICAL AND BIOCHEMICAL CHARACTERIZATION OF STRAINS OF Xanthomonas axonopodis pv. vignicola ISOLATED FROM COWPEA GROWN IN THREE AGROECOLOGICAL ZONES IN NIGERIA
}

\author{
OGUNTADE, O. ${ }^{1,2}$, OLUFOLAJI, D.B. ${ }^{2}$, OYETAYO, V.O. ${ }^{2}$, POPOOLA, A.R. ${ }^{3}$, KAZEEM ,S.A. ${ }^{4}$ AND \\ AYODELE M.A. ${ }^{1}$ \\ ${ }^{1}$ Germplasm Health Unit, IITA, P.M.B 5320, Oyo road. Ibadan Nigeria \\ ${ }^{2}$ Department of Crop, Soil and Pest Management, Federal University of Technology Akure \\ P.M.B. 704 Akure, Ondo State Nigeria \\ ${ }^{3}$ Crop Protection Department, Federal University of Agriculture Abeokuta P.M.B 2240, \\ Abeokuta Ogun State Nigeria \\ ${ }^{4}$ Post-Entry Quarantine, Surveillance and Diagnostic Station, Nigeria Agricultural \\ Quarantine Service, Moor Plantation, Ibadan, Nigeria \\ Corresponding author: o.oguntade@cgiar.org
}

\begin{abstract}
Cowpea bacterial blight (Xanthomonas axonopodis pv vignicola) is a devastating disease of cowpea in Nigeria. Accurate identification is the first step for an effective management option. Thus, X. axonopodis pv. vignicola isolated from cowpea (Vigna unguinculata (L.) Walp) grown in different Agro-ecological zones in Nigeria were characterized using morphological characteristics, biochemical and antibiotic sensitivity tests. Pot experiments were conducted on two susceptible lines of cowpea (IT90k - 76) and (IT84s - 2246 -4) in the screen house. In vivo infectivity studies were carried out to determine the effect of each of the $X$. axonopodis $p v$. vignicola isolate groups on the cowpea. All isolates from each of the agroecological zones were classified into Group 1 (light yellow) and Group 2 (brownish yellow) based on their morphological presentation on nutrient agar medium. Results from four of the biochemical test showed differences between the two morphologically different groups. Group 2 isolates showed a large zone of inhibition to a Lincomycin hydrochloride while isolates from Group 1 were not affected by the action of the same antibiotic. Blight symptom was only observed when the two types of isolates were combined and inoculated simultaneously. This study showed that there are two morpho-types of $X$. axonopodis $p v$. vignicola and their synergetic infectivity results in blight symptoms expression in cowpea.
\end{abstract}

Key words: Bacterial blight, Morpho-types, Isolates, synergy, antibiotics https://dx.doi.org/10.4314/jafs.v19i2.1

\section{INTRODUCTION}

Cowpea (Vigna unguinculata (L.) Walp.) is an important grain legume throughout the tropics and subtropics because it does well where other food legumes fail to perform. As food, cowpea is eaten in the form of grain, green pods, and leaves. The leaves also serve as forage (Ball et al., 2007) and a herb in most parts of Africa (Adejumo, 1997). The roots are eaten in Sudan and Ethiopia, and the peduncles and stems are used as fibers in Nigeria (Adejumo, 1997). Cowpea seeds contain $24 \%$ protein, $62 \%$ soluble carbohydrates, and small amounts of other nutrients (Jayathilak et al., 2018). Cowpea is cultivated on at least 12.57 million hectares in the world with an annual production of over 5.8million metric tons (FAO, 2019). Africa produces $95 \%$ of the world total and more than $66.75 \%$ of the world cowpea comes from the drier regions of Nigeria, Cameroon, Niger and Burkina Faso (FAO, 2019). Despite all the good agronomic attributes of this crop, the production constraints have been insects and diseases damage which often infest /infect the plant throughout its life cycle and storage (Singh et sl., 1990; Emechebe and Shoyinka, 1985; Vauterin et al., 1995;

Journal of the Faculty of Agriculture and Veterinary Medicine, Imo State University Owerri website: www ajol.info 
Journal of Agriculture and Food Sciences

Volume 19, Number 2, October 2021, pp 1 - 12.

Emechebe and Lagoke, 2002; Okechukwu and Ekpo, 2008; Kamara et al., 2013). Other constraints are drought, excessive moisture, temperature extremes, late maturity, and poor plant types (Muleba and Ezumah, 1985).

Bacterial diseases reported on cowpea are bacterial blight (Xanthomonas axonopodis $p v$. vignicola), bacterial pustule $(X$. axonopodis $p v$. vignae), bacterial wilt (Pseudomonas syringae pv. solanacearum) and halo blight ( $P$. syringae pv. tabaci) (Emechebe and Shoyinka, 1985; Emechebe and Florini, 1997; Okechukwu and Ekpo, 2008). Bacterial blight is one of the most destructive diseases in cowpea producing areas with widespread distribution (Patel, 1985; Vauterin et al., 1995; Okechukwu and Ekpo, 2008; Claudius-Cole et al., 2014) with bacterial pustule having limited distribution (Emechebe and Florini, 1997; Emechebe and Lagoke, 2002; Okechukwu and Ekpo, 2008; Claudius-Cole et al., 2014).Yield loss due to $X$. campestris pv. vignicola ranges between 3-100\% depending the strain, cultivars and stage of growth at the time of infection (Shoaga et al., 2001; Okechukwu and Ekpo 2008; Okechukwu et al., 2010). Among different strategies to control cowpea bacterial blight, the development of resistant cultivars would be most attractive to farmers (Emechebe and Shoyinka 1985; Khatri-Chhetri et al., 2003; Agbicodo et al., 2010) in Africa. Several reports (Okechukwu and Ekpo, 2004; Agbicodoet al., 2010; Duche et al., 2015) on resistance to $X$. campestris pv. vignicola exist but this largely depends on the isolates of the bacterium (Shoaga et al., 2001; Agbicodo et al., 2010; Okechukwu et al., 2010, Duche et al., 2015).

Identification of $X$. campestris pv. vignicola isolates from different agro-ecologies in Nigeria was mainly based only on virulence (Shoaga et al., 2001; Okechukwu and Ekpo, 2004; Agbicodo et al., 2010; Ganiyu et al., 2017; Durojaye et al., 2019) which could lead to non-repeatability of the experiment. Identification/characterization of a pathogen is a key for assessment of plant resistance,
Oguntade O., Olufolaji D.B., Oyetayo V.O., 2 Popoola A.R., Kazeem S.A. and Ayodele M.A.

ensure repeatability and reduce variability of experimental results. Information on the identity of strain peculiar to an agroecological zone is critical to efforts aimed at screening cowpea cultivars for resistance as this status is isolates/strains dependent. For example IT81D-1228-14 was reported resistant (Agbicodo et al., 2010) and susceptible (Durojaye et al., 2019), mainly due to use of different non-characterized isolates (Duche et al., 2015).Thus, the aim of this study was to characterize and determine the pathogenicity of different isolates of $X$. campestris pv. vignicola from three agro-ecological zones in Nigeria.

\section{MATERIALS AND METHOD}

\section{Sample collection site}

States in three agro-ecological zones of Guinea savanna (Kano, Kaduna, Niger), humid forest (Cross River, Ebonyi, Edo state) and rain forest (Oyo, Ogun, Ondo) in Nigeria were visited (Fig. 1). Three Local Government Areas (LGA) per state were visited with bacterial blight symptomatic leaves collected randomly on 1-2 month cowpea plants from three farmers' fields per LGA (243 fields in total) . Leaves were wrapped in used newspapers and labelled with the farm sites, geographical coordinate, and date of sampling and placed in a box.

\section{Isolation of bacterial blight pathogen}

Isolation of $X$. axonopodis $p v$ vignicola was carried out on each of the samples by excise about $2 \mathrm{~mm}$ of the infected site on the leaves and tease them in few drops of sterile distilled water and streaked on Nutrient agar (NA). This was incubated at $27^{\circ} \mathrm{C}$ for $48 \mathrm{hr}$ and was purified thereafter to obtain pure culture. Culture of $X$. axonopodis $p v$ vignicola was preserved on NA slant at $4^{\circ} \mathrm{C}$ until needed.

\section{MORPHOLOGICAL AND BIOCHEMICAL TESTS}

\section{Morphological characteristics}

Growth characteristics on Nutrient Agar, Gram test and Microscopic examination were used to determine the morphological characteristics. Isolates were streaked on 
Journal of Agriculture and Food Sciences

Volume 19, Number 2, October 2021, pp 1 - 12.

nutrient agar and incubated at $28^{\circ} \mathrm{C}$ for 48 hours. Growth color was recorded.

\section{Gram reaction}

Gram test of the isolates followed the Gram staining procedure of Schaad, (2001) Thinly spread bacterial smear was prepared on a clean slide, air-dried and fixed by passing thrice over a spirit lamp flame (. The smear was flooded with crystal violet solution (1 minute) and rinsed with distilled water for few seconds and excess water drained off and blot dried. It was followed by flooding with iodine solution (1 minute) and rinsed again with distilled water for few seconds and blot dried. The slide was flooded with decolorizer using 95\% ethanol until the solvent flow colorlessly from the slide and rinsed again with distilled water (2 seconds). The slide was counter stained for about 10s with Safranin, washed in distilled water, blot dried and examined under microscope using oil immersion objective (x100).

\section{Biochemical tests}

Five biochemical tests (Esculin hydrolysis, Oxidation/Fermentation, Starch hydrolysis, Milk proteolysis and Gelatin hydrolysis) and seven antibiotics were used to characterize the isolates and determine their reactions to different antibiotics respectively.

\section{Esculin Hydrolysis}

Esculin broth consists in $\mathrm{g} / \mathrm{l}$ of yeast extract, $5 \mathrm{~g} ; \mathrm{NaCl}, 5 \mathrm{~g} ; \mathrm{MgSO}_{4} .7 \mathrm{H}_{2} \mathrm{O}, 0.2 \mathrm{~g} \mathrm{~K} \mathrm{HPO}_{4}$, $0.5 \mathrm{~g} ; \mathrm{NH}_{4} \mathrm{H}_{2} \mathrm{PO}_{4}, 0.5 \mathrm{~g}$; ferric ammonium citrate $50 \mathrm{mg}$, and esculin (sigma) $1 \mathrm{~g}$, was prepared and adjusted to $\mathrm{pH}$ 6.8. About $7 \mathrm{mls}$ of the mixture was dispensed in glass vials and sterilized. A loopful of a $48 \mathrm{hr}$ bacterial culture was inoculated in each tube with the control left uninoculated on a rotating shaker at $28^{\circ} \mathrm{C}$. The reaction started after the $5^{\text {th }}$ day and readings was taken on the $10^{\text {th }}$ day. Complete Hydrolysis results in lack of UV light fluorescence of esculin

\section{Oxidation/Fermentation Test}

Eschenlauer et al., (2002) and Yendrembam et al., (2020) described a method for fermentation assays that avoid masking of
Oguntade O,. Olufolaji D.B, Oyetayo V.O., 3 Popoola A.R., Kazeem S.A. and Ayodele M.A.

acid production by ammonia production. The medium contains ( $\mathrm{g} / \mathrm{l})$ peptone, 2.0; $\mathrm{NaCl}, 5.0 ; \mathrm{KH}_{2} \mathrm{PO}_{4}, 0.3$; agar (Difco), 3.0 and $3 \mathrm{ml} / 1$ of a $1 \%$ aqueous solution of bromothymol blue. The compounds were dissolved and $\mathrm{pH}$ was adjusted to 7.1. The medium was dispensed $5 \mathrm{ml}$ aliquots into $13 \mathrm{~mm}$ diameter test tubes and sterilized at $121^{\circ} \mathrm{C}$ for $10-15 \mathrm{~min}$. A $10 \%$ glucose solution was filter sterilized and $0.5 \mathrm{ml}$ is aseptically added to each tube. Two tubes were stab inoculated for each of the isolate from each location. One was sealed with sterile liquid paraffin to a depth of $2 \mathrm{~cm}$ and the other was not. A color change in the anaerobic tube demonstrates glucose fermentation i.e. fermentation ability. Positive and negative controls consist of Erwinia and Pseudomonas isolates respectively.

\section{Starch Hydrolysis}

Nutrient agar plates containing $0.2 \%$ soluble starch (w/v) was prepared and inoculated with the different isolates and incubated at $28^{\circ} \mathrm{C}$ until growths occurred. Plates were then flooded with iodine solution (iodine $1.0 \mathrm{~g}$, potassium iodide $2.0 \mathrm{~g}$, distilled water $100 \mathrm{ml})$. A clear zone around a colony is a positive reaction for starch hydrolysis while negative reaction gives the blue-black stain of unutilized starch.

\section{Milk Proteolysis}

Reconstituted powdered milk with $40 \mathrm{mg} / \mathrm{l}$ of bromocresol purple was steamed sterilized for $30 \mathrm{~min}$, and these was done daily for three consecutive days, then the mixture was aseptically dispensed into sterile tubes and inoculated with the isolates using a loopful of cells and this was incubated at $27^{\circ} \mathrm{C}$, for 3 days. Casein (milk protein) digestion is indicated by clearing reaction after incubation.

\section{Gelatin hydrolysis}

Nutrient agar with $0.4 \%$ of gelatin was poured into Petri dishes, cooled and dried overnight. The plates were inoculated with the isolates and incubated at $27^{\circ} \mathrm{C}$ for 3 days. The plate surface was then flooded with $5 \mathrm{ml}$ mercuric chloride (Toxic) solution 
Journal of Agriculture and Food Sciences

Volume 19, Number 2, October 2021, pp 1 - 12.

$\left(\mathrm{HgCl}_{2}, \quad 12 \mathrm{~g}\right.$; distilled water, $80 \mathrm{mls}$; concentrated $\mathrm{HCl}, 16 \mathrm{ml}$ ). A clear zone surrounding bacterial growth indicates positive reaction for gelatin hydrolysis (Tille and Forbes, 2014).

\section{Antibiotics test}

Gentamycin (50ug/ml dissolved in water), Chloramphenicol $(20 \mathrm{ug} / \mathrm{ml}$ dissolved in Absolute ethanol), Streptomycin sulphate (50ug/ml dissolved in water), Lincomycin hydrochloride $(10 \mathrm{ug} / \mathrm{ml}$ dissolved in water), Vancomycin $(50 \mathrm{ug} / \mathrm{ml}$ dissolved in water), Phosphomycin (50ug/ml dissolved in water) and Cefazolin (10ug/ml dissolved in water) were used to determine the isolates reaction to different antibiotics.

Paper discs of about $6 \mathrm{~mm}$ diameter used in the experiments were improvised in the laboratory by cutting glass micro fibre filters into the required size needed for this work. Bacterial strains evaluated for sensitivity to antibiotics were prepared by suspending a loopful of $48 \mathrm{hr}$ - old bacterial culture in $20 \mathrm{ml}$ of sterile distilled water (SDW). The resulting bacterial suspension was then adjusted to an optical density of 0.06 at $620 \mathrm{~nm}$ (which corresponded to ca. $108 \mathrm{cfu} / \mathrm{ml}$ ). One micro liter of the bacterial suspension was spread on Nutrient agar surface in Petri dishes using a Drigalski spreader. Then, paper discs were soaked in the antibiotic's solution, laid on the agar surface and labelled accordingly. Inoculated plates were incubated at $28^{\circ} \mathrm{C}$ for $48 \mathrm{~h}$ and observed daily for growth inhibition zones around the paper discs. Radial inhibition zones around each disc, corresponding to the level of antibiotic activity for each treatment were measured using ruler.

\section{Pathogenicity test}

Pathogenicity test were conducted on two susceptible lines of cowpea (IT90k-76) and (IT84s-2246-4) in the screen house of Germplasm Health Unit in IITA in order to determine the infective capacity of $X$. axonopodis $p v$ vignicola isolates on the cowpea lines. Bacterial colonies from $24 \mathrm{hr}$ nutrient agar culture plates were washed off with sterile normal saline $(0.85 \mathrm{~g}$ of $\mathrm{NaCl}$ in Journal of the Faculty of Agriculture and Veterinary Medicine, Imo State University Owerri website: www ajol.info
Oguntade O,. Olufolaji D.B, Oyetayo V.O., 4 Popoola A.R., Kazeem S.A. and Ayodele M.A.

1 liter of SDW) into a conical flask. An inoculum concentration of $10^{6}$ colony forming unit $(\mathrm{CFU}) / \mathrm{ml}$ was prepared from this stock by using a Milton Roy spectrophotometer (Spectronic 21 model) set at a wavelength of $640 \mathrm{~nm}$. A bacteria concentration of $10^{7} \mathrm{CFU} / \mathrm{ml}$ is obtained when the optical density reading is 0.009 absorbance units (Myers et al., 2013). .

The prepared inoculum was stored in a $600 \mathrm{ml}$ conical flask in the refrigerator immediately after preparation. It was later transferred on ice prior to inoculation to inhibit proliferation of bacterial cells after counting. Inoculation was done within $35 \mathrm{~min}$ of calibration of the inoculum. The two isolates were inoculated individually on 2 weeks old plants from the two varieties in one set of the experiment while the two isolates were combine at $1: 1$ ratio to inoculates plants from the two accessions. The plants were covered with transparent polythene sheet to provide humidity for initiation of infection within $48 \mathrm{hr}$ after which this was removed and presence or absence of characteristic blight symptoms was recorded for up to 28 days.

\section{RESULT}

All isolates irrespective of agro-ecological zones have similar morphology and biochemical characteristics, thus Ebonyi, Mokwa and Ikenne isolates were selected to represent humid forest, Guinea savanna and rain forest respectively in the figures and tables. Isolates from each of the agroecological zones were Gram negative, mucoid, convex and had two colour presentations. These presentations were classified into two isolates: Isolate 1 light yellow and Isolate 2 brownish yellow (Fig. 2 ). Biochemical test conducted on the two isolates from each agro-ecological zone show that, the two isolates were negative to oxidation/fermentation test (Table 1). Isolate 1 (light yellow) from all the zones was negative to esculin, gelatin, starch and Milk proteolysis while all isolate 2 (brownish yellow) from each zones were positive to all the tests (Table 1). 
Journal of Agriculture and Food Sciences

Volume 19, Number 2, October 2021, pp 1 - 12.

Three out of the seven antibiotics used differentiated the isolates obtained from each agro-ecological zones (Table 2). Lincomycin hydrochloride restricted the growth of isolate 2 to form inhibitory zones around the antibiotics disc used whereas isolate 1 of each zone were able to grow on the same set of antibiotics disc (Fig. 3). On the contrary Isolate 1 formed inhibitory zones around the antibiotics disc where Vancomycin and Cefazolin was used, that is, the two antibiotics restricted the growth of the bacteria around where the discs containing the antibiotics were placed. Gentamycin, Chloramphenicol, Streptomycin sulphate and Phosphomycin did not inhibit any of the isolates, as all of them thrived on these antibiotics.

The screen house infectivity tests conducted on the two susceptible lines of cowpea showed that, each of the bacteria isolate types could not produce blight symptoms individually. Blight symptoms were obtained on the plants only when inoculation was done using a mixture of the two bacteria isolates types (Fig. 4).

\section{DISCUSSION AND CONCLUSION}

The study was conducted to characterize different strains/isolates of Xanthomonas axonopodis $p v$ vignicola from different locations in nine (9) states representing three agro-ecological zones of Nigeria. It washypothesized that resistance developed against a strain in a zone will not be effective on another strain in a different zone without appropriate information on the characteristics needed for identification of the isolates. Across the different zones visited, two different isolates of $X$. axonopodis $p v \quad$ vignicola were distinguishable from same infected plant samples collected, This was similar to the observation of Verdier et al. (1998) of two strains isolated from the same plant with different colony types but with same type of symptom. All the isolates obtained from the study irrespective of location showed phenotypic characteristics of Xanthomonas axonopodis $p v$. vignicola being Gram-
Oguntade O,. Olufolaji D.B, Oyetayo V.O., 5 Popoola A.R., Kazeem S.A. and Ayodele M.A.

negative, rod shaped with yellow, convex colonies (Nandini, 2012; Hayatu et al., 2013; Duche et al., 2015). These two isolates were tagged 1 and 2 based on their phenotypic expressions on culture medium, biochemical and antibiotic reagents suggesting the existence of strains/morphotypes of $X$. axonopodis $p v$ vignicola (Fourie et al., 2011;Nandini, 2012). Isolates 1 had similar phenotypic characteristics irrespective of location ditto for isolates 2, which confirms the report of Duche et al., 2015 of high levels of similarity within the same zone. The similar characteristics among the zones reveal seedborne patterns of pathogen migration. Farmers use and exchange their previous season's farm saved seeds which have been recycled over many years with build-up of seedborne pathogen which supported the reports of Claudius-Cole et al. (2014) and Ganiyu et al.(2017) that seeds contribute the largest percentage to the spread of $X$. axonopodis $p v$. vignicola). It also indicates that the colony colour can be used as an indicator of differences in strains/morphotypes.

On culture medium, isolate 1 was observed to be light yellow which is similar to the report of Nandini (2012) while isolate 2 was brownish yellow in this study but described by Nandini (2012) as pale/dark yellow. Duche et al. (2015) also reported variation in colour ranging from yellow to yellow creamy colony colour on nutrient agar medium with $5 \%$ glucose which was attributed to Xanthomonadin pigment production. Nevertheless, this also goes to show the need for characterization of the isolates before they can be used for further studies.

Studies on the two isolates (1 and 2) when subjected to esculin, gelatin,milk proteolysis and starch hydrolysis tests described by Aidan et al. (2012) shows that isolate 2 in each case completely hydrolyzed the medium while isolate 1 could not hydrolyze any of the media. Duche et al. (2015) reported different degree of variation in the 
Journal of Agriculture and Food Sciences

Volume 19, Number 2, October 2021, pp 1 - 12.

isolates to oxidase reaction, casein hydrolysis and starch hydrolysis which was attributed to variations among isolates. The biochemical reaction coupled with the pale yellow colony colour of isolate from Nandini (2012) gives an indication that it might be similar to isolate 2 from this study. This suggests that the colony colour and biochemical reactions can be used also to identify/characterize this pathogen.

Bioefficacy of different antibiotics used in this study indicated that Isolate 2 was inhibited by Lincomycin hydrochloride with no effect on isolate 1 . When vancomycin and cefazolin were used, the effect was only $\mathrm{n}$ isolate 1 . This observation supported the works by Nandini (2012) of differences in the isolate reaction based on the antibodies used indicating that the antibiotic reactions can also be used to rate the pathogens.

Pathogenic variation of isolates used in previous studies for assessments of resistance was mainly attributed to the symptom expression from the isolates (Duche et al.,2015; Durojaiye et al., 2019). Different strains within $X$. campestris pv. vignicola have been reported responsible for this variation based on the level of virulence on cowpea cultivars (Agbicodo, et al., 2010). This was described by Khatri-Chhetri et al. (2003) as low, medium and high virulence. In this study, virulence was obtained only when the two isolates were combined and co-inoculated. This was similar with Fourie et al. (2011) report on the use of two mixture of isolates (X6 and Xf105) for inoculation to improve symptom expression. This suggests that symptoms expression of a typical cowpea bacterial blight would only occur when the isolates from each of the two strains are present. This has been reported (Kaur et al., 2011; Lamichhane and Venturi, 2015) as pathogen-pathogen interactions or synergy
Oguntade O,. Olufolaji D.B, Oyetayo V.O., 6 Popoola A.R., Kazeem S.A. and Ayodele M.A.

which improves the ability of the pathogens to cause infection in combination than individually. The mechanism(s) for this synergy among different bacterial species is currently unknown (Lamichhane and Venturi, 2015).

In this study, we found that purification of colonies to differentiate the two isolates is important to prevent unintended synergy between the isolates which will gives false information on the virulence of the isolates. We also agree with Verdier et al. (1998) and Khatri-Chhetri et al. (2003) that strains of $X$. axonopodis $p v$ vignicola, as well as those found from this study acting synergistically, belonged to the same pathovar based on our findings on pathological, biochemical and antibiotic tests. We support the view of Verdier et al. (1998) and Duche et al. (2015) of the non-existence of races or distinct pathovars of $X$. axonopodis $p v$ vignicola. In our view, this pathogenic variation are results of synergism among the different strains, however this hypothesis needs further molecular clarification as done for strains of $X$. oryzae pv. oryzae (Vera Cruz et al., 1996). Thus, these synergistic interactions is important for the understanding of pathogenesis of the strains in cowpea for the development of effective disease control strategies as suggested by Lamichhane and Venturi (2015).

It is therefore evident from the study that the two morphotypes isolates are different and react in synergy to produce symptoms of bacterial blight which is contrary to a lot of research earlier done on this pathogen. Further research, which could not be undertaken due to paucity of funds, needs to focus on molecular characterization of the strains from different zones and molecular mechanism of host-pathogen interactions to enhance understanding and promote efforts in managements of the disease. 
Journal of Agriculture and Food Sciences

Volume 19, Number 2, October 2021, pp 1 - 12

\section{REFERENCES}

Adejumo, T.O. (1997). Identification, incidence, severity and methods of control of the causal organism of false smut diseases of cowpea Vigna unguiculata (L.) Walp. PhD thesis, University of Ibadan, Nigeria.

Agbicodo, E.M., Fatokun, C.A. Bandyopadhyay, R., Wydra, K., Diop, N.N., Muchero, W., Ehlers, J.D., Roberts, P.A., Close, T.J., Vissser, R.G.F., \& Van der Linden C.G. (2010). Identification of markers associated with bacterial blight resistance loci in cowpea [Vigna unguiculata (L.) Walp]. Euphytica, 175, 215-226. https://doi.org/10.1007/s10681-0100164-5

Aidan, P.,Whitman, W.B., Goodfellow, M., Kämpfer, P.,Hans-Jürgen, B., Trujillo, M.E., \& Wolfgang Ludwig, K.S.(2012). Bergey's Manual of systematic bacteriology: Volume 5. The Actinobacteria New York: Imprint: Springer.

Ball, D.M., Hoveland, C.S., \& Lacefield. G.D. (2007). Southern forages: modern concepts for forage crop management. 4th ed. International Plant Nutrition Institute (IPNI), Norcross, GA.

Claudius-Cole, A.O., Ekpo, E.J.A.,\& Schilder, A.M.C. (2014). Evaluation of detection methods for cowpea bacterial blight caused by Xanthomonas axonopodis pv vignicola in Nigeria. Tropical Agricultural Research \& Extension, 17(2), 77-85. https://doi.org/10.4038/tare.v17i2.5310

Duche, T. R., Iheukwumere, C.C. \& Omoigui, L. (2015). Evaluation of Selected Cowpea Genotypes for Resistance to Bacterial Blight. International Journal of Current Microbiology and Applied Sciences, 4(6), 257-270.
Oguntade O,. Olufolaji D.B, Oyetayo V.O., 7 Popoola A.R., Kazeem S.A. and Ayodele M.A.

Durojaye, H.A., Moukoumbi Y.D., Dania V.O., Boukar, O., Bandyopadhyay R. \& Ortega-Beltran, A. (2019). Evaluation of cowpea (Vigna unguiculata (L.) Walp.) landraces to bacterial blight caused by Xanthomonas axonopodis pv. vignicola. Crop Protection, 116, 77-81. https://doi.org/10.1016/j.cropro.2018.10. 013

Emechebe, A.M. \& Shoyinka, S.A. (1985). Fungal and bacteria diseases of cowpea in Africa. Pp 173-197.In: Cowpea research, production and utilization. Singh, S.R. \& Rachie, K.O. (eds). John Wiley \& Ltd. Chichester, Great Britain.

Emechebe, A.M., \& Florini, D.A. (1997). Shoot and pod diseases of cowpea induced by fungi and bacteria. Pp 176192. In Advances in cowpea research. Singh, B.B., Mohan, D.R., Dashiell, K.E., Jackie, E.N., (eds.) Co-publication of International Institute of Tropical Agriculture (IITA) and Japan International Research Centre for Agricultural Science.

Emechebe, A.M., \& Lagoke, S.T.O. (2002). Recent advances in research on cowpea diseases. pp 94-123.In: Fatokun, C.A., Tarawali, S.A., Singh, B.B., Kormawa, P.M., Tamo, M. (eds) Challenges and opportunities for enhancing sustainable cowpea production. Proceedings of the World Cowpea Conference III held at the International Institute of Tropical Agriculture (IITA), Ibadan, Nigeria, 4-8 September 2002. IITA, Ibadan Nigeria.

Eschenlauer, S.C.P., McKain, N., Walker, N.D., McEwan, N.D., Newbold, C.J., \&Wallace, R.J. (2002). Ammonia Production by Ruminal Microorganisms and Enumeration, Isolation, and Characterization of Bacteria Capable of Growth on Peptides and Amino Acids from the Sheep Rumen. Applied and Environmental Microbiology, 68(10), 4925-4931. 
Journal of Agriculture and Food Sciences

Volume 19, Number 2, October 2021, pp 1 - 12. https://doi.org/10.1128/AEM.68.10.4925 $-4931.2002333$

FAO (2019). Food and Agricultural Organization (FAO) Statistics. Retrieved 29th January, 2019. http://faostat.fao.og

Fourie, D., Herselman, L., \& Mienie, C. (2011). Improvement of common bacterial blight resistance in South African dry bean cultivar Teebu. African Crop Science Journal, 19 (4), 377 - 386.

Ganiyu, S., Popoola, A., Owolade, O. \& Fatona, K., (2017). Control of common bacterial blight disease of cowpea (Vigna unguiculata [L.] Walp) with certain plant extracts in Abeokuta, Nigeria. Journal of Crop Improvement, 31 , 280-288. https://doi.org/10.1080/15427528.2017. 1299065

Hayatu, M., Kutama, A.S., Aisha, W.A. \& Nura, S. (2013). Screening of some genotypes of cowpea (Vigna unguiculata [L.] Walp) against bacterial blight caused by Xanthomonas campestris pv translucens. Global Advanced Research Journal of Agricultural Science, 2(10), 276-282.

Jayathilak, C., Visvanathan, R., Deen, A., Bangamuwage, R., Jayawardana, B.C., Nammi, S. \& Liyanage, R. (2018). Cowpea: an overview on its nutritional facts and health benefits. Journal of the Science of Food and Agriculture 98, 4793-4806. https://doi.org/10.1002/jsfa.9074

Kamara, A.Y., Ewansiha, S.U., Ajeigbe, H.A. \&Omoigui, L.O. (2013). Response of old and new cowpea varieties to insecticide spray in the Sudan savanna of Nigeria. Archives of Phytopathology and Plant Protection, 46(1), 52-63. https://doi.org/10.1080/03235408.2012. 734714

Kaur, P., Sivasithamparam,K., Li,H., \& Barbetti, M.J. (2011). Pre-inoculation
Oguntade O,. Olufolaji D.B, Oyetayo V.O., 8 Popoola A.R., Kazeem S.A. and Ayodele M.A.

with Hyaloperonospora parasitica reduces incubation period and increases severity of disease caused by Albugocandida in a Brassica juncea variety resistant to downy mildew. Journal of General Plant Pathology, 77, 101-106.

https://doi.org/10.1007/s10327-0110293-2

Khatri-Chhetri, G.B., Wydra, K \& Rudolph, K. (2003). Metabolic diversity of Xanthomonas axonopodis pv. vignicola, causal agent of cowpea bacterial blight and pustule. European Journal of Plant Pathology, 109,851-860. https://doi.org/10.1023/A:10261047166 50

Lamichhane, J.R. \& Venturi, V. (2015) Synergisms between microbial pathogens in plant disease complexes: a growing trend. Fronier Plant Science, 6, 1-12. https://doi.org/10.3389/fpls.2015.00385

Muleba, N. \& Ezumah, H.C. (1985). Optimizing cultural practices for cowpea in Africa. Pages 289-295. In: Cowpea research, production and utilization. Singh, S.R. and K.O. Rachie (eds.). John wiley and Sons Ltd. Great Britain. 460pp.

Myers, J.A., Curtis, B.S. \& Curtis, W.R. (2013). Improving accuracy of cell and chromophore concentration measurements using optical density. BMC Biophys., $6, \quad 4$. https://doi.org/10.1186/2046-1682-6-4

Nandini R. (2012). Studies on bacterial blight of cowpea caused by Xanthomonas axonopodis pv. vignicola (Burkh.) University of Agricultural Science MSc thesis, Dharwad, India. 97pp.

Okechukwu, R.U. \& Ekpo, E.J.A. (2008). Survival of Xanthomonas campestris pv. vignicola in infested soil, cowpea seed and cowpea debris. Trop Agriculture 
Journal of Agriculture and Food Sciences

Volume 19, Number 2, October 2021, pp 1 - 12

Research \& Extension 11, 43-48. https://doi.org/10.4038/tare.v11i0.1787

Okechukwu, R.U., \& Ekpo, E.J.A. (2004). Sources of resistance to cowpea bacterial blight disease in Nigeria. Journal of Phytopathology, 152, 345351. https://doi.org/10.1111/j.14390434.2004.00852.x

Okechukwu, R.U., Ekpo, E.J.A, Okechukwu, O.C. (2010). Seed to plant transmission of Xanthomonas campestris pv. vignicola isolates in cowpea. African Journal of Agricultural Research, 5, 431-435.

Patel, P.N. (1985). Pathogen variability and host resistance in bacterial pustule disease of cowpea in Africa. Tropical Agriculture (Trinidad), 58(3), 275 - 280.

Schaad, N.W. (2001). Initial Identification of common genera. P1-16. In Schaad N.W., Jones, J.B. and Chun, W. (Eds.). Laboratory Guide for Identification of Plant Pathogenic Bacteria. 3rd Edition. APS press. St Paul, Minnesota, USA.373pp.

Shoaga, O.A., Okechukwu,R.U.,\& Ekpo, E.J.A. (2001). Comparative virulence of bacterial blight (Xanthomonas campestris pv. vignicola) isolates and their effect on yield components of cowpea (Vigna unguiculata). Tropical Agricultural Research and Extension, 4(2), 76-79.

Singh, S.R., Jackai, L.E.N., Dos Santos, J.H.R., \&Adalla, C.B. (1990). Insect pests of cowpea. In: Singh, S.R. (ed.)
Oguntade O,. Olufolaji D.B, Oyetayo V.O., 9 Popoola A.R., Kazeem S.A. and Ayodele M.A.

Insect pests of food legumes. Chichester (UK): John Wiley and Sons Ltd. p.43-8

Tille, P. M., \& Forbes, B. A. (2014). Bailey \& Scott's diagnostic microbiology (Thirteenth edition.). St. Louis, Missouri: Elsevier

Vauterin, L., Hoste, B., Kersters, K., \& Swings, J. (1995). Reclassification of Xanthomonas. International Journal of Systemic Bacteriology, 45, 472-489. https://doi.org/10.1099/00207713-45-3472

Vera Cruz, C.M., Ardales, E., Skinner, R.J., Talag, J., Nelson, R.J., Louws, F.J., Leung, H., Mew, T.W., \& Leach, J.E. (1996). Measurement of haplotypic variation in Xanthomonas oryzae pv. oryzae within a single field by rep-PCR and RFLP analyses. Phytopathology, 86, 1352-1359.

Verdier, V., Assigbetse, K., Khatri-Chhetri G., Wydra, K., Rudolph, K. \& Geiger, JP. (1998). Molecular characterization of the incitant of cowpea bacterial blight and pustule, Xanthomonas campestris pv. Vignicola. European Journal of Plant Pathology, 104, 595-602. https://doi.org/10.1023/A:10086105174 37

Yendrembam, M.C., Shyam, S.P., Avijit, D., \& Satbir, S.D. (2020). Reducing Ruminal Ammonia Production with Improvement in Feed Utilization Efficiency and Performance of Murrah Buffalo (Bubalus bubalis) Through Dietary Supplementation of Plant-Based Feed Additive Blend. Frontier in Veterinary Science, 18, https://doi.org/10.3389/fvets.2020.00464 


\section{APPENDIX}

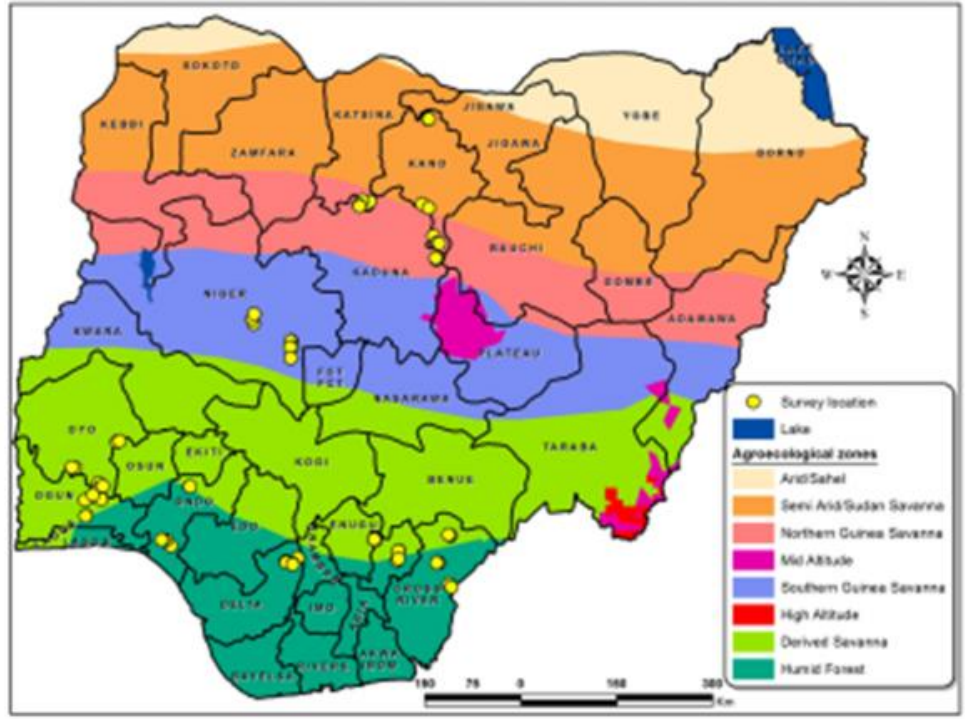

Fig. 1 Map showing collection sites in different agro-ecological zones in Nigeria

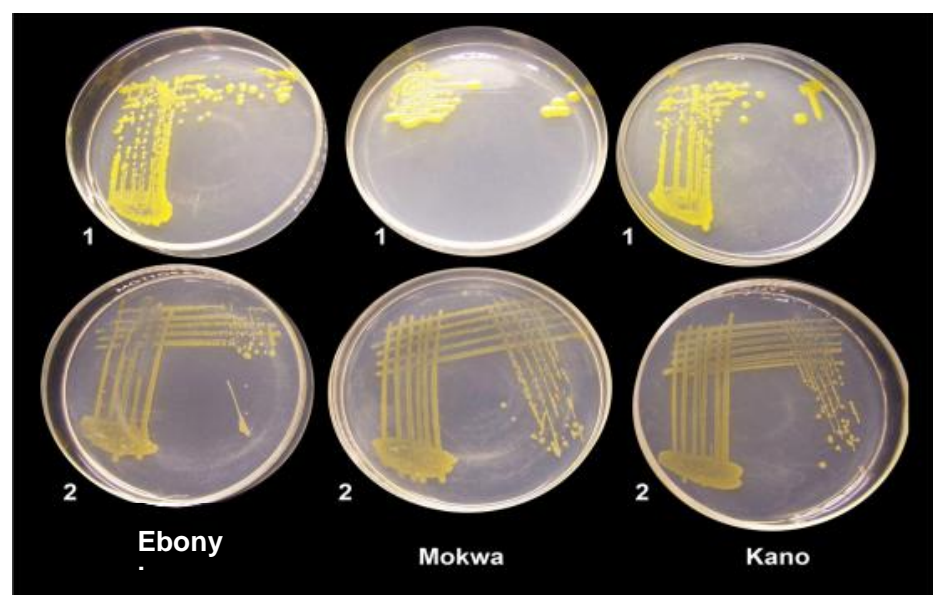

Fig. 2 Isolates of Xanthomonas axonopodis pv vignicola from different agroecological zones with colour presentations of (1) light yellow (2) brownish yellow

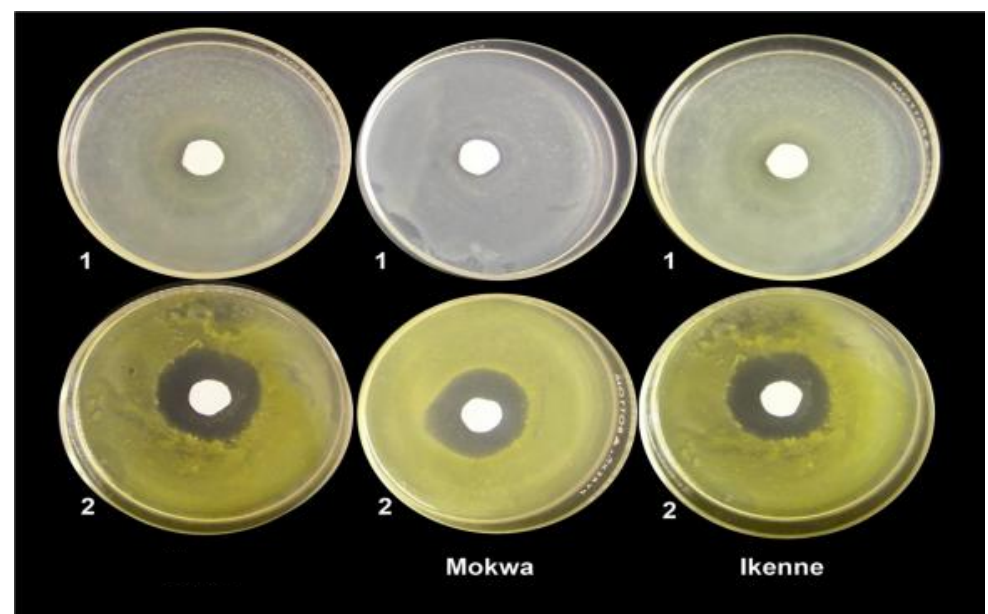

Fig.3 Growth of isolate on Lincomycin hydrochloride

Journal of the Faculty of Agriculture and Veterinary Medicine, Imo State University Owerri website: www ajol.info 
Table 1: Biochemical reactions of the Isolates from each of the agro-ecological zones

\begin{tabular}{|c|c|c|c|c|c|}
\hline Samples & $\begin{array}{l}\text { Oxidation/ } \\
\text { Fermentation }\end{array}$ & Esculin Hydrolysis & $\begin{array}{l}\text { Starch } \\
\text { Hydrolysis }\end{array}$ & Milk Proteolysis & $\begin{array}{l}\text { Gelatine } \\
\text { Hydrolysis }\end{array}$ \\
\hline \multicolumn{6}{|l|}{ Ikenne } \\
\hline Isolate 1 & $-\mathrm{ve}$ & - ve & - ve & - ve & - ve \\
\hline Isolate 2 & - ve & + ve & + ve & + ve & + ve \\
\hline \multicolumn{6}{|l|}{ Mokwa } \\
\hline Isolate & & & & & \\
\hline $\begin{array}{l}1 \\
\text { Isolate }\end{array}$ & - ve & - ve & - ve & - ve & - ve \\
\hline 2 & - ve & $+\mathrm{ve}$ & + ve & + ve & + ve \\
\hline \multicolumn{6}{|l|}{ Ebonyi } \\
\hline Isolate & & & & & \\
\hline $\begin{array}{l}1 \\
\text { Isolate }\end{array}$ & - ve & - ve & - ve & - ve & - ve \\
\hline 2 & - ve & $+\mathrm{ve}$ & $+\mathrm{ve}$ & $+\mathrm{ve}$ & $+\mathrm{ve}$ \\
\hline
\end{tabular}

Table 2: Effect of antibiotics on the two isolates of Xanthomonas axonopodis pv vignicola

\begin{tabular}{lcc}
\hline Antibiotics & Isolate 1 & Isolate 2 \\
\hline Gentamycin & - & - \\
Chloramphenicol & - & - \\
Streptomycin sulphate & - & - \\
Lincomycin hydrochloride & - & + \\
Vancomycin & + & - \\
Phosphomycin & - & - \\
Cefazolin & + & - \\
& &
\end{tabular}



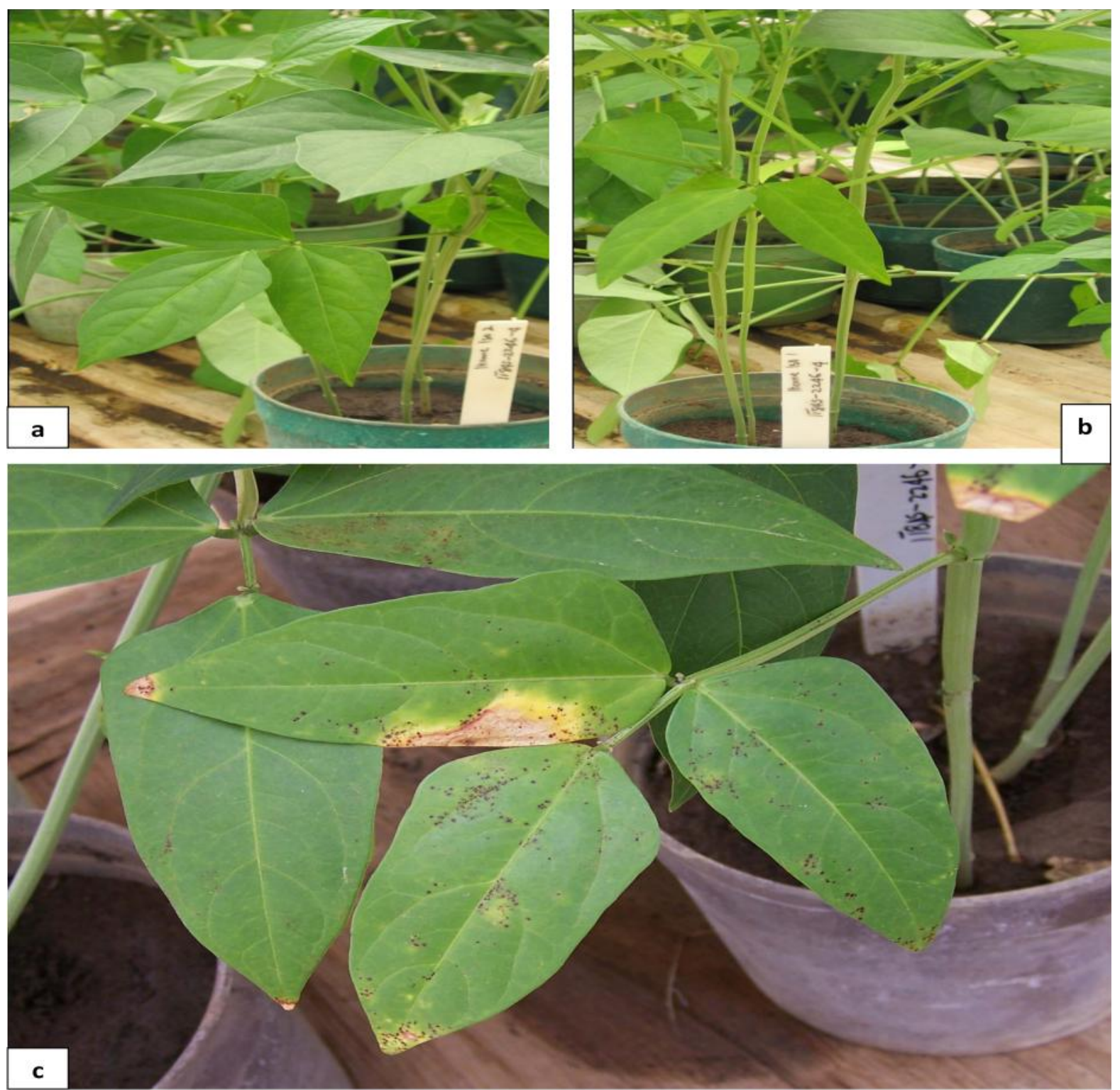

Figure 3:Cowpea plants (a) and (b) without blight symptom after 15 days of inoculation with isolate 1 and isolate 2 bacteria respectively and (c) with blight symptoms after 15 days inoculation with combined isolates of $1 \& 2$ bacteria. 